\section{A) Check for updates}

Cite this: Inorg. Chem. Front., 2020, 7, 4445

Received 24th June 2020, Accepted 6th September 2020

DOI: 10.1039/d0qi00746c

rsc.li/frontiers-inorganic

\title{
2.2.2-Cryptand as a bidentate ligand in rare-earth metal chemistry $\dagger$ :
}

\author{
Amanda B. Chung, (D) Daniel N. Huh, (D) Joseph W. Ziller (D) and William J. Evans (D)*
}

The 2.2.2-cryptand ligand (crypt) that is heavily used in reductions of rare-earth metal complexes to encapsulate alkali metals has been found to function as a bidentate ligand to rare-earth metal ions in some cases. The $\mathrm{X}$-ray crystal structures of the reduced dinitrogen metal complex, $\left[\left\{\left(\mathrm{R}_{2} \mathrm{~N}\right)_{2} \mathrm{Ce}\left(\mathrm{crypt}-\kappa^{2}-\mathrm{O}\right.\right.\right.$, $\left.\left.\left.\mathrm{O}^{\prime}\right)\right\}_{2}\left(\mu-\eta^{2}: \eta^{2}-\mathrm{N}_{2}\right)\right]\left(R=\mathrm{SiMe}_{3}\right)$, and the ytterbium metallocene, $\left(\mathrm{C}_{5} \mathrm{Me}_{5}\right)_{2} \mathrm{Yb}\left(\mathrm{crypt}-\kappa^{2}-\mathrm{O}, \mathrm{O}^{\prime}\right)$, are presented to demonstrate this binding mode. The implications of this available binding mode in rare-earth metal cryptand chemistry are discussed.

\section{Introduction}

One of the recent advances in rare-earth metal chemistry has been the discovery of crystallographically-characterizable molecular complexes of La(II), Ce(II), Pr(II), Gd(II), Tb(II), Ho(II), Er(II), $\mathrm{Lu}(\mathrm{II})$, and $\mathrm{Y}$ (II) according to syntheses such as those shown in eqn (1). ${ }^{1-9}$

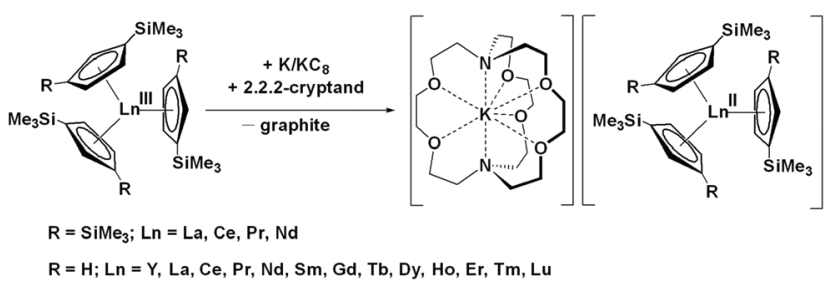

Prior to those discoveries, molecular complexes of +2 lanthanide ions were known only for $\mathrm{Eu}(\mathrm{II}), \mathrm{Yb}(\mathrm{II}), \mathrm{Sm}(\mathrm{II}), \mathrm{Tm}(\mathrm{II}), \mathrm{Dy}(\mathrm{II})$, and $\mathrm{Nd}(\mathrm{II}) .{ }^{6,7,10-13}$ The reduction reactions that generated the new $\operatorname{Ln}(\mathrm{II})$ ions utilized the 2.2.2-cryptand ligand (crypt) extensively to

Department of Chemistry, University of California, Irvine, California 92697-2025, USA.E-mail: wevans@uci.edu

$\dagger$ Dedicated to Professor Xu Guangxian for his extensive efforts in research as "the father of Chinese rare-earth chemistry" and for his excellent teaching which has generated an ongoing legacy of outstanding students.

\$Electronic supplementary information (ESI) available. CCDC 2011829. For ESI and crystallographic data in CIF or other electronic format see DOI: 10.1039/ d0qi00746c encapsulate the alkali metal ion formed in the reaction. The cryptchelated alkali metal units constituted good counter-cations for the $\left(\mathrm{Cp}_{3}^{\prime} \mathrm{Ln}^{\mathrm{II}}\right)^{1-}$ and $\left(\mathrm{Cp}_{3}{ }_{3} \mathrm{Ln}^{\mathrm{II}}\right)^{1-}$ anions $\left(\mathrm{Cp}^{\prime}=\mathrm{C}_{5} \mathrm{H}_{4} \mathrm{SiMe}_{3} ; \mathrm{Cp}^{\prime \prime}=\right.$ $\left.\mathrm{C}_{5} \mathrm{H}_{3}\left(\mathrm{SiMe}_{3}\right)_{2}\right)$, shown in eqn (1), which facilitated crystallographic characterization of the reaction products. Ln(II) metal complexes are now known with $[\mathrm{M}(\text { crypt })]^{1+}$ counter-cations for $\mathrm{M}=\mathrm{Li}, \mathrm{Na}, \mathrm{K}$, $\mathrm{Rb}$, and $\mathrm{Cs}$ in structures such as $[\mathrm{Li}($ crypt $)]\left[\mathrm{Cp}_{3}^{\prime} \mathrm{Ln}\right]{ }^{14}$ $[\mathrm{Na}($ crypt $\left.)]\left[\mathrm{Cp}_{3}^{\prime} \mathrm{Ln}\right]\right]^{15}[\mathrm{~K}($ crypt $)]\left[\mathrm{Cp}_{3}{ }_{3} \mathrm{Ln}\right]{ }^{1,9}[\mathrm{~K}($ crypt $)]\left[\mathrm{Cp}^{\text {tet }}{ }_{3} \mathrm{Ln}\right](\mathrm{Ln}=$ La, Ce, Pr, Nd, Sm, Gd, Tb, Dy); $\left(\mathrm{Cp}^{\text {tet }}=\mathrm{C}_{5} \mathrm{Me}_{4} \mathrm{H}\right),{ }^{16}$ $[\mathrm{K}($ crypt $)]\left[\mathrm{Cp}_{3}^{\mathrm{t}} \mathrm{Dy}\right]_{2}\left(\mathrm{Cp}^{\mathrm{t}}=\mathrm{C}_{5} \mathrm{H}_{4} \mathrm{CMe}_{3}\right),{ }^{17}[\mathrm{~K}($ crypt $)]\left[\mathrm{Cp}^{\mathrm{Me}}{ }_{3} \mathrm{Dy}\right]\left(\mathrm{Cp}^{\mathrm{Me}}=\right.$ $\left.\mathrm{C}_{5} \mathrm{H}_{4} \mathrm{Me}\right){ }^{18}[\mathrm{~K}(\mathrm{crypt})]\left[\mathrm{Sc}\left(\mathrm{OAr}^{\prime}\right)_{3}\right]\left(\mathrm{OAr}^{\prime}=\mathrm{OC}_{6} \mathrm{H}_{2}-\mathrm{t}-\mathrm{Bu}_{2}-2,6-\mathrm{Me}-4\right){ }^{19}[\mathrm{~K}$ (crypt)][(( $\left.\left.\left.{ }^{\mathrm{Ad}, \mathrm{Me}} \mathrm{ArO}\right)_{3} \mathrm{mes}\right) \mathrm{Ln}\right]\left(\mathrm{Ln}=\mathrm{Nd}, \mathrm{Gd}, \mathrm{Dy}, \mathrm{Er} ;\left({ }^{\mathrm{Ad}, \mathrm{Me}} \mathrm{ArO}\right)_{3}\right.$ mes = (2-Ad-4-Me- $\left.\mathrm{C}_{6} \mathrm{H}_{2} \mathrm{O}\right)_{3}\left(2,4,6-\mathrm{Me}_{3} \mathrm{C}_{6} \mathrm{H}_{2}\right) ; \quad \mathrm{Ad}=1$-adamantyl), ${ }^{8} \quad[\mathrm{~K}$ (crypt) $)\left[\mathrm{Y}\left(\mathrm{OAr}{ }^{\mathrm{Ad}, \mathrm{Ad}, t-\mathrm{Bu}}\right)_{3}\right]\left(\mathrm{OAr}^{\mathrm{Ad}, \mathrm{Ad}, t-\mathrm{Bu}}=2,6-\mathrm{Ad}_{2}-4-t-\mathrm{Bu}^{-} \mathrm{C}_{6} \mathrm{H}_{2} \mathrm{O}\right),{ }^{20}[\mathrm{Rb}$ $($ crypt $)]\left[\mathrm{Ln}\left(\mathrm{NR}_{2}\right)_{3}\right](\mathrm{Ln}=\mathrm{Nd}, \mathrm{Ho}, \mathrm{Er}),{ }^{21}$ and $[\mathrm{Cs}(\mathrm{crypt})]\left[\mathrm{Sc}\left(\mathrm{NR}_{2}\right)_{3}\right](\mathrm{R}=$ $\left.\mathrm{SiMe}_{3}\right){ }^{22}$ Additionally, the crypt ligand in $[\mathrm{Li}(\text { crypt })]^{1+}$ countercations has also been found as crypt- $\mathrm{\kappa}^{6}$ in three different binding modes: $\mathrm{N}_{2} \mathrm{O}_{4},{ }^{14,23} \mathrm{NO}_{5},{ }^{14,23-29}$ and $\mathrm{O}_{6} \cdot{ }^{14}$

However, the crypt ligand can also encapsulate rare-earth metals ions as well as alkali metal ions. A variety of such metal complexes have been crystallographically-characterized involving both divalent and trivalent ions usually with one or two additional coordinated ligands that could be anions or neutral species. Examples include $\left[\operatorname{Ln}^{\mathrm{II}}(\operatorname{crypt})(\mathrm{THF})_{x}\right]\left[\mathrm{Cp}_{3}^{\prime} \mathrm{Ln}\right]$ $(x=1$, Ln $=\mathrm{Sm}, \mathrm{Eu} ; x=0, \mathrm{Ln}=\mathrm{Yb}),{ }^{30}\left[\mathrm{Sm}^{\mathrm{II}}(\right.$ crypt $)$ (DippForm)][DippForm] (DippForm $=N, N^{\prime}$-bis(2,6-diisopropylphenyl)-formamidinate) $,^{31} \quad\left[\mathrm{Sm}^{\mathrm{II}}(\mathrm{crypt})(\mathrm{PCO})_{2}\right],{ }^{31} \quad\left[\mathrm{Eu}^{\mathrm{II}}(\mathrm{crypt})\right.$ $\mathrm{Cl}][\mathrm{Cl}],{ }^{32} \quad\left[\mathrm{Yb}^{\mathrm{II}}(\mathrm{crypt}) \mathrm{I}\right][\mathrm{I}],{ }^{33} \quad\left[\mathrm{Ln}^{\mathrm{II}}(\mathrm{crypt})(\mathrm{THF})\right]\left[\mathrm{BPh}_{4}\right]_{2} \quad(\mathrm{Ln}=$ $\mathrm{Sm}, \mathrm{Eu}),{ }^{34}\left[\mathrm{La}^{\mathrm{III}}(\mathrm{crypt}) \mathrm{Cl}_{2}\right][\mathrm{Cl}],{ }^{35}\left[\mathrm{Ln}^{\mathrm{II}}(\mathrm{crypt})(\mathrm{DMF})_{x}\right][\mathrm{X}]_{2}(x=2, \mathrm{Ln}=$ $\left.\mathrm{Sm}, \mathrm{Eu} ; x=1, \mathrm{Ln}=\mathrm{Yb} ; \mathrm{X}=\mathrm{I}, \mathrm{BPh}_{4}\right),{ }^{36}\left[\mathrm{Ln}^{\mathrm{III}}(\mathrm{crypt})(\mathrm{OTf})_{2}\right][\mathrm{OTf}]$ and $\left[\operatorname{Ln}^{\mathrm{II}}(\mathrm{crypt})(\mathrm{OTf})_{2}\right](\mathrm{Ln}=\mathrm{Nd}, \mathrm{Sm})^{37}$ among others. ${ }^{38-42}$

We report here a new coordination mode for crypt with rareearth metal ions that is intermediate between the two modes described above, i.e. it is in between the 8-coordinate mode with the 
rare-earth metal ion inside crypt and the situation in which crypt is not coordinating the rare-earth metal ion at all. We describe here two crystal structures that show that crypt can function as a bidentate ligand to rare-earth ions. This has interesting implications in the reaction chemistry of rare-earth metal complexes involving crypt.

\section{Results and discussion}

The first example of a bidentate crypt metal complex of a rareearth metal ion was discovered while examining the reduction of dinitrogen with $\mathrm{Ce}\left(\mathrm{NR}_{2}\right)_{3}\left(\mathrm{R}=\mathrm{SiMe}_{3}\right)$ and potassium graphite. Numerous $\mathrm{LnA}_{3} / \mathrm{M}$ reactions ( $\mathrm{A}=$ anion; $\mathrm{M}=$ alkali metal) of this type have been performed in the past and generated both $(\mathrm{N}=\mathrm{N})^{2-}$ and $\left(\mathrm{N}_{2}\right)^{3-}$ metal complexes. ${ }^{43-48}$ For example, crystallographically-characterized examples of $\left[\left(\mathrm{R}_{2} \mathrm{~N}\right)_{2}(\mathrm{THF})\right.$ $\mathrm{Ln}]_{2}\left(\mu-\eta^{2}: \eta^{2}-\mathrm{N}_{2}\right)$ have been isolated in this way from reactions in THF for the smaller rare-earths, $\mathrm{Ln}=\mathrm{Nd}, \mathrm{Gd}, \mathrm{Tb}$, Dy, Ho, Y, Er, Tm, and Lu, eqn (2). ${ }^{44}$

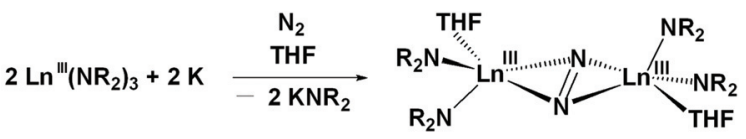

Ln = Nd, Gd, Tb, Dy, Ho, Y, Er, Tm, Lu

$\mathrm{R}=\mathrm{SiMe}_{3}$
Analogous reactions with the larger lanthanides, La, Ce, and $\mathrm{Pr}$, appeared to proceed similarly, but crystallographic confirmation of the products was not obtained. ${ }^{1} \mathrm{H}$ and ${ }^{15} \mathrm{~N}$ NMR data on the La product were similar to those on the $\mathrm{Y}$ and $\mathrm{Lu}$ products. ${ }^{4,46}$ Hence, it was likely that $(\mathrm{N}=\mathrm{N})^{2-}$ products of $\mathrm{La}$, Ce, and Pr formed, but the metal complexes were too sterically unsaturated with these larger metals to crystallize well. Further evidence of reaction in eqn (2) with the large lanthanides was obtained by isolation and crystallographic characterization of the tetrakis(amide) products, $\left[\mathrm{K}(\mathrm{THF})_{6}\right]\left[\mathrm{Ln}\left(\mathrm{NR}_{2}\right)_{4}\right]$ for $\mathrm{La}$ and $\mathrm{Pr}$ and $\left[\mathrm{Na}\left(\mathrm{THF}_{4}\right)\right.$ $\left.\left(\mathrm{Et}_{2} \mathrm{O}\right)\right]\left[\mathrm{Ce}\left(\mathrm{NR}_{2}\right)_{4}\right]$ for Ce. These tetrakis(amides) can form by complexation to the $\mathrm{Ln}\left(\mathrm{NR}_{2}\right)_{3}$ starting material of the $\left(\mathrm{NR}_{2}\right)^{1-}$ ligands lost by each metal in a successful dinitrogen reduction. ${ }^{44}$

When the $\mathrm{LnA}_{3} / \mathrm{M}$ reaction was conducted in $\mathrm{Et}_{2} \mathrm{O}$ using Ce $\left(\mathrm{NR}_{2}\right)_{3}$ and $\mathrm{KC}_{8}$ in the presence of crypt, the $(\mathrm{N}=\mathrm{N})^{2-}$ metal complex, $\left[\left\{\left(\mathrm{R}_{2} \mathrm{~N}\right)_{2} \mathrm{Ce}\left(\text { crypt- } \kappa^{2}-\mathrm{O}, \mathrm{O}^{\prime}\right)\right\}_{2}\left(\mu-\eta^{2}: \eta^{2}-\mathrm{N}_{2}\right)\right]$, 1, was isolated and identified by X-ray diffraction, eqn (3), Fig. 1. This was the first cerium amide $(\mathrm{N}=\mathrm{N})^{2-}$ metal complex that could be crystallized.

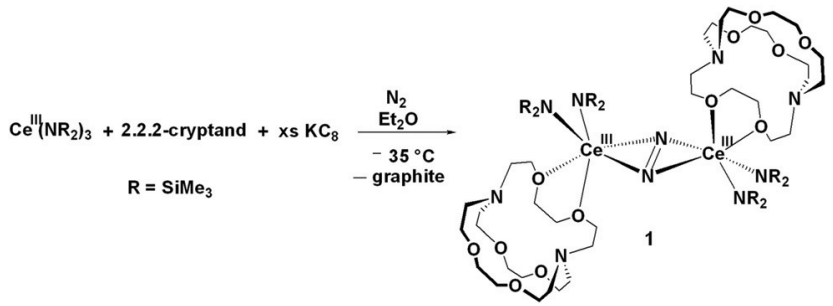

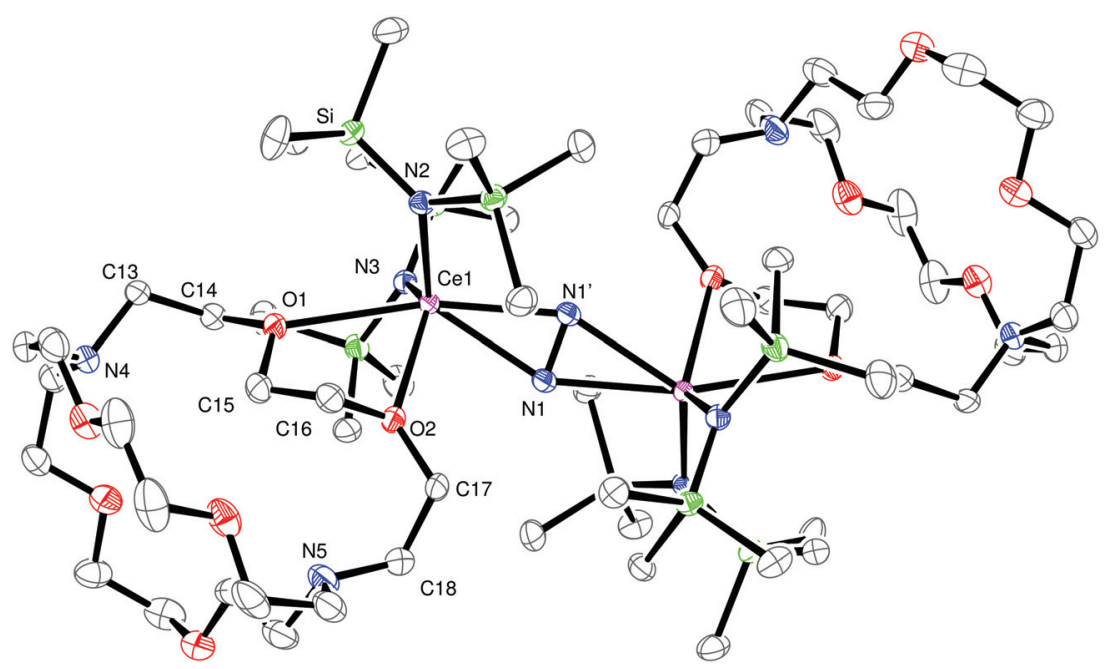

Fig. 1 ORTEP representation of $\left[\left\{\left(R_{2} N\right)_{2} C e\left(c r y p t-\kappa^{2}-O, O\right)\right\}_{2}\left(\mu-\eta^{2}: \eta^{2}-N_{2}\right)\right], 1$, with thermal ellipsoids drawn at the $50 \%$ probability level. Hydrogen atoms and an $\mathrm{Et}_{2} \mathrm{O}$ in the lattice are excluded for clarity. 
The crystal structure of $\mathbf{1}$, shows that it is a neutral metal complex with a side-on bound $(\mathrm{N}=\mathrm{N})^{2-}$ and two amide ligands bound to each cerium. This is similar to the known series of THF adducts in eqn (2), $\left[\left\{(\mathrm{THF})\left(\mathrm{R}_{2} \mathrm{~N}\right)_{2} \operatorname{Ln}\right\}_{2}\left(\mu-\eta^{2}: \eta^{2}-\right.\right.$ $\left.\mathrm{N}_{2}\right)$ ], ${ }^{44}$ except instead of one THF molecule per metal, a crypt ligand coordinates to each metal through two oxygen atoms. In this case, crypt is acting as a $\kappa^{2}-\mathrm{O}, \mathrm{O}^{\prime}$ "exo-crypt" with binding similar to that of a dimethoxyethane (DME) ligand. Presumably, with the extra steric bulk of crypt versus THF, the $\mathrm{Ce}(\mathrm{N}=\mathrm{N})^{2-}$ product is sterically saturated enough to allow isolation and crystallization.

Compound $\mathbf{1}$ is sparingly soluble in both toluene and benzene. A ${ }^{1} \mathrm{H}$ NMR spectrum was taken in both toluene- $\mathrm{d}_{8}$ and $\mathrm{C}_{6} \mathrm{D}_{6}$ (see ESI $\$$ ). The crypt resonances align with free cryptand in solution and only one resonance is seen for the methyl group of the silyl amides, which is shifted upfield.

The 1.233(4) $\AA \mathrm{N}-\mathrm{N}$ distance in $\mathbf{1}$ is similar to those in the metal complexes in eqn (2), 1.258(3)-1.305(6) $\AA$, and is consistent with a double bond, i.e. $(\mathrm{N}=\mathrm{N})^{2-} \cdot{ }^{49,50}$ The exo-crypt in 1 does not bind symmetrically and has $\mathrm{Ce}-\mathrm{O}$ distances in 1 of

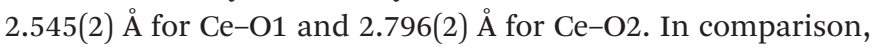
the $\mathrm{Ce}-\mathrm{O}(\mathrm{THF})$ distances in the cyclopentadienyl cerium dinitrogen complexes, $\left[\left(\mathrm{C}_{5} \mathrm{Me}_{5}\right)_{2}(\mathrm{THF}) \mathrm{Ce}\right]_{2}\left[\mu-\eta^{2}: \eta^{2}-\mathrm{N}_{2}\right]$ and $\left[\left(\mathrm{C}_{5} \mathrm{Me}_{4} \mathrm{H}\right)_{2}(\mathrm{THF}) \mathrm{Ce}\right]_{2}\left[\mu-\eta^{2}: \eta^{2}-\mathrm{N}_{2}\right]$, are 2.607(4) $\AA$ and 2.589(3) $\AA$, respectively. ${ }^{46}$ Hence, the crypt coordination could also be described as a monodentate ligand with a long secondary interaction. The 2.545(2) $\AA \mathrm{Ce}-\mathrm{O}$ (crypt) distance is similar to the $2.518(1) \AA \mathrm{Nd}-\mathrm{O}(\mathrm{THF})$ distance in $\left[\left(\mathrm{R}_{2} \mathrm{~N}\right)_{2}(\mathrm{THF})\right.$ $\mathrm{Nd}]_{2}\left(\mu-\eta^{2}: \eta^{2}-\mathrm{N}_{2}\right)$ when the $0.027 \AA$ ionic radius increase from $\mathrm{Nd}$ to Ce is considered. ${ }^{51}$

Within the coordinated crypt, the 1.437(3)-1.443(3) A C-O distances involving the coordinating $\mathrm{O} 1$ and $\mathrm{O} 2$ are within the error limits of the other 1.399(4)-1.424(4) ^ C-O distances, as shown in Table 1. The $\mathrm{C}-\mathrm{C}$ distances and the angles involving the bound oxygen atoms are similar to those in the rest of the crypt molecule.

A second example of exo-crypt coordination was found in the reaction of $\left(\mathrm{C}_{5} \mathrm{Me}_{5}\right) \mathrm{Yb}\left(\mathrm{BPh}_{4}\right)$ with crypt in toluene. This reaction was explored to determine if ligand redistribution

Table 1 Selected distances $(\AA)$ and angles $\left(^{\circ}\right)$ for 1

\begin{tabular}{llll}
\hline Ce1-N3(amide) & $2.409(2)$ & Ce1-N1 & $2.451(2)$ \\
Ce1-N2(amide) & $2.411(2)$ & Ce1-N1' & $2.468(2)$ \\
Ce1-O1 & $2.7957(18)$ & Ce1-O2 & $2.5453(18)$ \\
N1-N1' & $1.233(4)$ & & \\
Crypt O-C distance & & & \\
O1-C14 & $1.439(3)$ & O1-C15 & $1.437(3)$ \\
O2-C16 & $1.438(3)$ & O2-C17 & $1.443(3)$ \\
O3-C20 & $1.422(4)$ & O3-C21 & $1.418(4)$ \\
O4-C22 & $1.413(4)$ & O4-C23 & $1.418(4)$ \\
O5-C26 & $1.424(4)$ & O5-C27 & $1.417(4)$ \\
O6-C28 & $1.413(4)$ & O6-C29 & $1.399(4)$ \\
Crypt C-C distance & & & \\
C13-C14 & $1.525(4)$ & C15-C16 & $1.485(4)$ \\
C17-C18 & $1.512(4)$ & C19-C20 & $1.504(4)$ \\
C21-C22 & $1.489(5)$ & C23-C24 & $1.507(5)$ \\
C25-26 & $1.510(4)$ & C27-C28 & $1.495(5)$ \\
C29-C30 & $1.525(5)$ & &
\end{tabular}

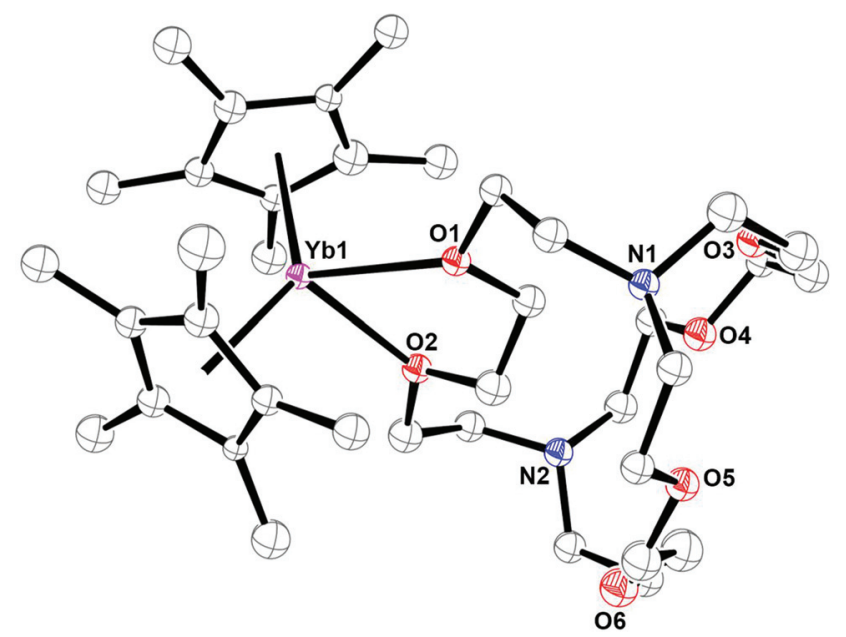

Fig. 2 Structure of $\left(\mathrm{C}_{5} \mathrm{Me}_{5}\right)_{2} \mathrm{Yb}\left(\mathrm{crypt}-\kappa^{2}-\mathrm{O}, \mathrm{O}^{\prime}\right), 2$, showing the bidentate binding of crypt.

would occur to form an $\mathrm{Yb}$ (II)-in-crypt product. ${ }^{30}$ However, ligand rearrangement occurred to form a bis(cyclopentadienyl) metallocene which crystallized with crypt bound as a bidentate ligand, $\left(\mathrm{C}_{5} \mathrm{Me}_{5}\right)_{2} \mathrm{Yb}$ (crypt- $\left.\kappa^{2}-\mathrm{O}, \mathrm{O}^{\prime}\right), 2$, eqn (4), Fig. 2. The compound was identified by X-ray crystallography, but the data were not of high enough quality for a detailed structural discussion. In the metal complex 2 , as in 1 , the exo-crypt ligand coordinates like DME. X-ray crystal structures of similar formally eight coordinate $\left(\mathrm{C}_{5} \mathrm{Me}_{5}\right)_{2} \mathrm{YbL}_{2}$ compounds are common with $\mathrm{L}=$ pyridine $^{52}$ and with $\mathrm{L}_{2}=$ bipyridine and substituted bipyridines. $^{53,54}$

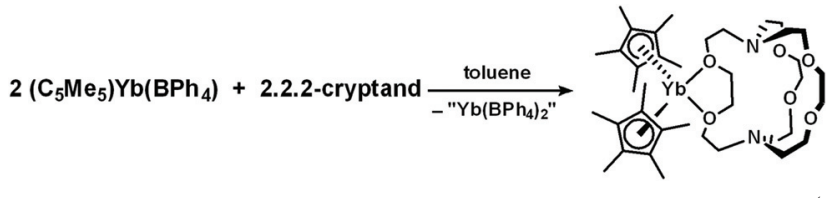

\section{Conclusion}

Although 2.2.2-cryptand can stabilize alkali metal ions to generate favorable lattices for crystallization of rare-earth metal complexes and it can encapsulate rare-earth ions as an octadentate ligand, it can also function as a stabilizing bidentate $\kappa^{2}$-chelating ligand for rare-earth metal ions as shown in $\left[\left\{\left(\mathrm{R}_{2} \mathrm{~N}\right)_{2} \mathrm{Ce}\left(\text { crypt- } \kappa^{2}-\mathrm{O}, \mathrm{O}^{\prime}\right)\right\}_{2}\left(\mu-\eta^{2}: \eta^{2}-\mathrm{N}_{2}\right)\right], \quad \mathbf{1}$, and $\left(\mathrm{C}_{5} \mathrm{Me}_{5}\right)_{2} \mathrm{Yb}$ (crypt- $\left.\kappa^{2}-\mathrm{O}, \mathrm{O}^{\prime}\right), 2$. The diverse nature of these two metal complexes suggests that crypt could coordinate to rare-earth metal ions in a variety of different coordination environments.

Similar to these crypt- $\kappa^{2}-\mathrm{O}, \mathrm{O}^{\prime}$ binding modes, 18-crown-6 (18-c-6) rare-earth metal complexes are known in which not all 
O-donors are coordinated. Two scandium metal complexes containing $\left[\mathrm{ScCl}_{2}\left(\kappa^{5}-18-\mathrm{c}-6\right)\right][\mathrm{X}]\left(\mathrm{X}=\mathrm{SbCl}_{6} \text { or } \mathrm{FeCl}_{4}\right)^{55,56}$ and $[\mathrm{Ce}$ $\left.\left(\kappa^{2}-18-c-6\right)\right]\left[\mathrm{N}\left(\mathrm{SiMe}_{3}\right) \mathrm{PhF}\right]_{3} \quad(\mathrm{PhF}=\text { pentafluorophenyl })^{57}$ have been reported.

To the extent that crypt binds like dimethoxyethane, it constitutes a sterically bulky variation of this commonly-used ether. The size and 3-dimensional nature of crypt means that it can substantially fill the coordination environment of a sterically unsaturated compound. In the case of the $\left[\left\{\left(\mathrm{R}_{2} \mathrm{~N}\right)_{2} \operatorname{Ln}\right\}_{2}\left(\mu-\eta^{2}: \eta^{2}-\mathrm{N}_{2}\right)\right]$, which crystallizes for smaller metals, $\mathrm{Nd}-\mathrm{Lu}$, but not for $\mathrm{Ce}$, it is possible that a single THF ligand was not enough to sterically saturate the coordination environment to yield single crystals for X-ray diffraction. Crypt coordination in $\mathbf{1}$ led to successful crystallization of this cerium $(\mathrm{N}=\mathrm{N})^{2-}$ compound. Attempts to crystallize “[ $\left.\left\{\left(\mathrm{R}_{2} \mathrm{~N}\right)_{2} \mathrm{Ce}\right\}_{2}\left(\mu-\eta^{2}: \eta^{2}-\mathrm{N}_{2}\right)\right]$ ", with DME have been unsuccessful.

The efficacy of crypt in $\mathbf{2}$ is somewhat different since the $\left(\mathrm{C}_{5} \mathrm{Me}_{5}\right)_{2} \mathrm{Yb}$ unit crystallizes in the absence of any ethers and with one and two coordinating ligands. ${ }^{52-54,58-60}$ Hence, this is not the case of a sterically unsaturated unit that will not crystallize. The $\kappa^{2}$-crypt just functions as other bidentate coordinating bases.

These results raise interesting possibilities in reaction chemistry. It is possible that crypt can coordinate to a rareearth metal ion before alkali metal reduction occurs and before the alkali metal cation is formed and inserts into the crypt. Similarly, in the reactions that form Ln-in-crypt [Ln (crypt) $]^{n+}$ cations, ${ }^{30,35-37}$ a preliminary step in the procedure could involve bidentate coordination of the crypt to the rareearth metal ion before it inserts into the cavity. The importance of $\kappa^{2}$-crypt coordination in any reaction coordinate will depend heavily on the specific system, the solvent, and any other ligands present in the reaction mixture. However, in non-polar solvents free of any other coordinating ligands, $\kappa^{2}$-crypt could play an important role as a bidentate ligand that preferentially stabilizes species that are otherwise not isolable.

\section{Experimental}

All manipulations and syntheses described below were conducted with the rigorous exclusion of air and water using standard Schlenk line and glovebox techniques under an argon or dinitrogen atmosphere. Solvents were sparged with UHP argon and dried by passage through columns containing Q-5 and molecular sieves prior to use. Deuterated NMR solvents were dried over NaK alloy or Na/benzophenone, degassed by three freeze-pump-thaw cycles, and vacuum-transferred before use. ${ }^{1} \mathrm{H}$ NMR spectra were recorded on a Bruker AVANCE 600 spectrometer $\left({ }^{1} \mathrm{H}\right.$ operating at $\left.600 \mathrm{MHz}\right)$ at $298 \mathrm{~K}$, unless otherwise stated, and referenced internally to residual protio-solvent resonances. 2.2.2-Cryptand (Sigma-Aldrich) was placed under vacuum $\left(10^{-3}\right.$ Torr $)$ before use. $\mathrm{Ce}\left(\mathrm{NR}_{2}\right)_{3}{ }^{61}$ and $\left(\mathrm{C}_{5} \mathrm{Me}_{5}\right) \mathrm{Yb}$ $\left(\mathrm{BPh}_{4}\right)^{62}$ were synthesized according to literature procedures.

\section{$\left[\left\{\left(\mathbf{R}_{2} \mathbf{N}\right)_{2} \mathrm{Ce}\left(\text { crypt- }^{2}-\mathbf{O}, \mathbf{O}^{\prime}\right)\right\}_{2}\left(\mu-\eta^{2}: \eta^{2}-\mathbf{N}_{2}\right)\right], \mathbf{1}$}

A dinitrogen-saturated $\mathrm{Et}_{2} \mathrm{O}(3 \mathrm{~mL})$ solution of $\mathrm{Ce}\left(\mathrm{NR}_{2}\right)_{3}(\mathrm{R}=$ $\mathrm{SiMe}_{3}$ ) (60 mg, $0.1 \mathrm{mmol}$ ) and 2.2.2-cryptand (36 mg, $0.1 \mathrm{mmol}$ ), chilled to $-35{ }^{\circ} \mathrm{C}$, was added to a vial containing excess $\mathrm{KC}_{8}(20 \mathrm{mg} 0.1 \mathrm{mmol})$, that had been chilled in a cold well with a liquid nitrogen bath. This generated a yellow solution. Bright yellow crystals were isolated by filtering and placing the $\mathrm{Et}_{2} \mathrm{O}$ solution in $\mathrm{a}-35^{\circ} \mathrm{C}$ freezer for several days (20 mg, 24\%). These were identified as 1 by X-ray diffraction.

\section{$\left(\mathrm{C}_{5} \mathrm{Me}_{5}\right)_{2} \mathrm{Yb}\left(\right.$ crypt- $\left.^{2}-\mathrm{O}, \mathrm{O}^{\prime}\right), 2$}

In an argon atmosphere, the addition of a green toluene-solution of $\left(\mathrm{C}_{5} \mathrm{Me}_{5}\right) \mathrm{Yb}\left(\mathrm{BPh}_{4}\right)(50 \mathrm{mg}, 0.08 \mathrm{mmol})$ to a toluene (2 mL) solution of 2.2.2-cryptand (30 mg, $0.08 \mathrm{mmol}$ ) generated a green mixture with white precipitate. The mixture was filtered to remove insoluble material and the green solution was layered into hexanes and placed in a $-35^{\circ} \mathrm{C}$ freezer. After $1 \mathrm{~d}$, green X-ray quality crystals of 2 were formed.

\section{Conflicts of interest}

There are no conflicts to declare.

\section{Acknowledgements}

We thank the U. S. National Science Foundation for support of this research under CHE-1855328. We also thank Chen Sun for assistance with X-ray crystallography and David H. Woen for sample preparation.

\section{Notes and references}

1 P. B. Hitchcock, M. F. Lappert, L. Maron and A. V. Protchenko, Lanthanum Does Form Stable Molecular Compounds in the +2 Oxidation State, Angew. Chem., Int. Ed., 2008, (47), 1488-1491.

2 M. R. MacDonald, J. W. Ziller and W. J. Evans, Synthesis of a Crystalline Molecular Complex of $\mathrm{Y}^{2+}$, [(18-Crown-6) $\mathrm{K}]\left[\left(\mathrm{C}_{5} \mathrm{H}_{4} \mathrm{SiMe}_{3}\right)_{3} \mathrm{Y}\right]$, J. Am. Chem. Soc., 2011, 133(40), 1591415917.

3 M. R. MacDonald, J. E. Bates, M. E. Fieser, J. W. Ziller, F. Furche and W. J. Evans, Expanding Rare-Earth Oxidation State Chemistry to Molecular Complexes of Holmium(II) and Erbium(II), J. Am. Chem. Soc., 2012, 134(20), 8420-8423.

4 M. R. Macdonald, E. Bates, J. W. Ziller, F. Furche and W. J. Evans, Completing the Series of +2 Ions for the Lanthanide Elements: Synthesis of Molecular Complexes of $\mathrm{Pr}^{+2}, \mathrm{Gd}^{+2}, \mathrm{~Tb}^{+2}$, and $\mathrm{Lu}^{+2}$, J. Am. Chem. Soc., 2013, 135, 9857-9868.

5 M. E. Fieser, M. R. Macdonald, B. T. Krull, J. E. Bates, J. W. Ziller, F. Furche and W. J. Evans, Structural, Spectroscopic, and Theoretical Comparison of Traditional vs Recently Discovered $\operatorname{Ln}^{2+}$ Ions in the $[\mathrm{K}(2.2 .2-$ 
Cryptand $)]\left[\left(\mathrm{C}_{5} \mathrm{H}_{4} \mathrm{SiMe}_{3}\right)_{3} \mathrm{Ln}\right]$ Complexes: The Variable Nature of $\mathrm{Dy}^{2+}$ and $\mathrm{Nd}^{2+}, J$. Am. Chem. Soc., 2015, 137(1), 369-382.

6 W. J. Evans, Tutorial on the Role of Cyclopentadienyl Ligands in the Discovery of Molecular Complexes of the Rare-Earth and Actinide Metals in New Oxidation States, Organometallics, 2016, 35, 3088-3100.

7 D. H. Woen and W. J. Evans, Expanding the +2 Oxidation State of the Rare-Earth Metals, Uranium, and Thorium in Molecular Complexes, in Handbook on the Physics and Chemistry of Rare Earths, Elsevier B.V., 2016, pp. 1-57.

8 M. E. Fieser, C. T. Palumbo, H. S. La Pierre, D. P. Halter, V. K. Voora, J. W. Ziller, F. Furche, K. Meyer and W. J. Evans, Comparisons of Lanthanide/Actinide +2 Ions in a Tris(aryloxide)arene Coordination Environment, Chem. Sci., 2017, 8(11), 7424-7433.

9 C. T. Palumbo, L. E. Darago, C. J. Windorff, J. W. Ziller and W. J. Evans, Trimethylsilyl versus Bis(trimethylsilyl) Substitution in Tris(cyclopentadienyl) Complexes of La, Ce, and Pr: Comparison of Structure, Magnetic Properties, and Reactivity, Organometallics, 2018, 37(6), 900-905.

10 L. R. Morss, Thermochemical Properties of Yttrium, Lanthanum, and the Lanthanide Elements and Ions, Chem. Rev., 1975, 76(6), 827-841.

11 N. B. Mikheev and A. N. K. Complex, Formation of the Lanthanides and Actinides in Lower Oxidation States, Coord. Chem. Rev., 1991, 109, 1-59.

12 M. N. Bochkarev, Molecular Compounds of "New" Divalent Lanthanides, Coord. Chem. Rev., 2004, 248(9-10), 835-851.

13 F. Nief, Molecular Chemistry of the Rare-Earth Elements in Uncommon Low-Valent States, in Handbook on the Physics and Chemistry of Rare Earths, 2010, pp. 241-300.

14 D. N. Huh, L. E. Darago, J. W. Ziller and W. J. Evans, Utility of Lithium in Rare-Earth Metal Reduction Reactions to Form Nontraditional $\mathrm{Ln}^{2+}$ Complexes and Unusual [Li (2.2.2-Cryptand) $]^{1+}$ Cations, Inorg. Chem., 2018, 57(4), 2096-2102.

15 M. E. Fieser, PhD Dissertation, University of California, Irvine, 2015.

16 T. F. Jenkins, D. H. Woen, L. N. Mohanam, J. W. Ziller, F. Furche and W. J. Evans, Tetramethylcyclopentadienyl Ligands Allow Isolation of $\operatorname{Ln}($ II) Ions across the Lanthanide Series in $[\mathrm{K}(2.2 .2$-Cryptand $)]\left[\left(\mathrm{C}_{5} \mathrm{Me}_{4} \mathrm{H}\right)_{3} \mathrm{Ln}\right]$ Complexes, Organometallics, 2018, 37(21), 3863-3873.

17 M. A. Angadol, D. H. Woen, C. J. Windorff, J. W. Ziller and W. J. Evans, tert-Butyl(cyclopentadienyl) Ligands Will Stabilize Nontraditional +2 Rare-Earth Metal Ions, Organometallics, 2019, 38(5), 1151-1158.

18 D. N. Huh, J. W. Ziller and W. J. Evans, Isolation of Reactive Ln(II) Complexes with $\mathrm{C}_{5} \mathrm{H}_{4} \mathrm{Me}$ Ligands $\left(\mathrm{Cp}^{\mathrm{Me}}\right)$ Using Inverse Sandwich Countercations: Synthesis and Structure of $\left[(18-C r o w n-6) \mathrm{K}\left(\mu-\mathrm{Cp}^{\mathrm{Me}}\right) \mathrm{K}(18-C r o w n-6)\right]\left[\mathrm{Cp}^{\mathrm{Me}}{ }_{3} \mathrm{Ln}^{\mathrm{II}}\right](\mathrm{Ln}=$ Tb, Ho), Dalton Trans., 2018, 47(48), 17285-17290.

19 S. A. Moehring, M. J. Beltrán-Leiva, D. Páez-Hernández, R. Arratia-Pérez, J. W. Ziller and W. J. Evans, Rare-Earth Metal(II) Aryloxides: Structure, Synthesis, and EPR
Spectroscopy of $[\mathrm{K}(2.2 .2$-Cryptand $)]\left[\mathrm{Sc}\left(\mathrm{OC}_{6} \mathrm{H}_{2} \mathrm{tBu}_{2}-2,6-\mathrm{Me}-\right.\right.$ 4) 3 ], Chem. - Eur. J., 2018, 24(68), 18059-18067.

20 S. A. Moehring, M. Miehlich, C. J. Hoerger, K. Meyer, J. W. Ziller and W. J. Evans, A Room-Temperature Stable Y(II) Aryloxide: Using Steric Saturation to Kinetically Stabilize Y(II) Complexes, Inorg. Chem., 2020, 59(5), 32073214 .

21 A. J. Ryan, L. E. Darago, G. Balasubramani, G. P. Chen, J. W. Ziller, F. Furche, J. R. Long and W. J. Evans, Synthesis, Structure, and Magnetism of Tris(amide) $\left[\operatorname{Ln}\left\{\mathrm{N}\left(\mathrm{SiMe}_{3}\right)_{2}\right\}_{3}\right]^{1-}$ Complexes of the Non-traditional +2 Lanthanide Ions, Chem. - Eur. J., 2018, 2, 7702-7709.

22 D. H. Woen, G. P. Chen, J. W. Ziller, T. J. Boyle, F. Furche and W. J. Evans, Solution Synthesis, Structure, and $\mathrm{CO}_{2}$ Reduction Reactivity of a Scandium(II) Complex, [Sc $\left.\left(\mathrm{N}\left(\mathrm{SiMe}_{3}\right)_{2}\right)_{3}\right]^{-}$, Angew. Chem., 2017, 129, 2082-2085.

23 S. D. Han, J. L. Allen, E. Jónsson, P. Johansson, D. W. McOwen, P. D. Boyle and W. A. Henderson, Solvate Structures and Computational/Spectroscopic Characterization of Lithium Difluoro(oxalato)borate (LiDFOB) Electrolytes, J. Phys. Chem. C, 2013, 117(11), 5521-5531.

24 C. Tirla, N. Mézailles, L. Ricard, F. Mathey and P. Le Floch, Dianionic Platinadiphospholene Complexes, Inorg. Chem., 2002, 41(23), 6032-6037.

25 A. Moores, L. Ricard, P. Le Floch and N. Mézailles, First X-Ray Crystal Study and DFT Calculations of Anionic $\lambda^{4}$-Phosphinines, Organometallics, 2003, 22(9), 1960-1966.

26 I. A. Guzei, L. C. Spencer, J. W. Su and R. R. Burnette, LowTemperature Enantiotropic $k 2$ Phase Transition in the Ionic 222-Cryptand Complex with $\mathrm{LiClO}_{4}$, Acta Crystallogr., Sect. B: Struct. Sci., 2007, 63(1), 93-100.

27 P. Alex Rudd, N. Planas, E. Bill, L. Gagliardi and C. C. Lu, Dinitrogen Activation at Iron and Cobalt Metallalumatranes, Eur. J. Inorg. Chem., 2013, 2(22-23), 3898-3906.

28 M. K. Assefa, G. Wu and T. W. Hayton, Synthesis of a Terminal Ce(Iv) Oxo Complex by Photolysis of a Ce(III) Nitrate Complex, Chem. Sci., 2017, 8(11), 7873-7878.

29 E. Lu, J. T. Boronski, M. Gregson, A. J. Wooles and S. T. Liddle, Silyl-Phosphino-Carbene Complexes of Uranium(Iv), Angew. Chem., Int. Ed., 2018, 57(19), 55065511.

30 D. N. Huh, C. M. Kotyk, M. Gembicky, A. L. Rheingold, J. W. Ziller and W. J. Evans, Synthesis of Rare-Earth-Metalin-Cryptand Dications, $[\operatorname{Ln}(2.2 .2 \text {-Cryptand })]^{2+}$, from $\mathrm{Sm}^{2+}$, $\mathrm{Eu}^{2+}$, and $\mathrm{Yb}^{2+}$ Silyl Metallocenes $\left(\mathrm{C}_{5} \mathrm{H}_{4} \mathrm{SiMe}_{3}\right)_{2} \mathrm{Ln}(\mathrm{THF})_{2}$, Chem. Commun., 2017, 53(62), 8664-8666.

31 S. Bestgen, Q. Chen, N. H. Rees and J. M. Goicoechea, Synthesis and Reactivity of Rare-Earth Metal Phosphaethynolates, Dalton Trans., 2018, 47(37), 1301613024.

32 C. U. Lenora, F. Carniato, Y. Shen, Z. Latif, E. M. Haacke, P. D. Martin, M. Botta and M. J. Allen, Structural Features of Europium(II)-Containing Cryptates That 
Influence Relaxivity, Chem. - Eur. J., 2017, 23(61), 1540415414.

33 T. C. Jenks, A. N. W. Kuda-Wedagedara, M. D. Bailey, C. L. Ward and M. J. Allen, Spectroscopic and Electrochemical Trends in Divalent Lanthanides through Modulation of Coordination Environment, Inorg. Chem., 2020, 59(4), 2613-2620.

34 M. L. Marsh, F. D. White, D. S. Meeker, C. D. McKinley, D. Dan, C. Van Alstine, T. N. Poe, D. L. Gray, D. E. Hobart and T. E. Albrecht-Schmitt, Electrochemical Studies of Selected Lanthanide and Californium Cryptates, Inorg. Chem., 2019, 58(15), 9602-9612.

35 D. N. Huh, C. J. Windorff, J. W. Ziller and W. J. Evans, Synthesis of Uranium-in-Cryptand Complexes, Chem. Commun., 2018, 54(73), 10272-10275.

36 D. N. Huh, J. W. Ziller and W. J. Evans, Facile Encapsulation of $\mathrm{Ln}$ (II) Ions into Cryptate Complexes from $\mathrm{LnI}_{2}(\mathrm{THF})_{2}$ Precursors ( $\mathrm{Ln}=\mathrm{Sm}$, Eu, Yb), Inorg. Chem., 2019, 58(15), 9613-9617.

37 D. N. Huh, S. R. Ciccone, S. Roy, J. W. Ziller, F. Furche and W. J. Evans, Synthesis of Ln(II)-in Cryptand Complexes by Chemical Reduction of Ln(III)-in-Cryptand Precursors, Angew. Chem., Int. Ed., 2020, 59, 16141-16146.

38 J. H. Burns, Crystal and Molecular Structure of a Cryptate Complex of Samarium: $\mathrm{C}_{18} \mathrm{H}_{36} \mathrm{O}_{6} \mathrm{~N}_{2} \mathrm{Sm}_{2}\left(\mathrm{NO}_{3}\right)_{6} \cdot \mathrm{H}_{2} \mathrm{O}$, Inorg. Chem., 1979, 18(11), 3044-3047.

39 B. M. Ciampolini, P. Dapporto and N. Nardi, Structure and Properties of Some Lanthanoid(III) Perchlorates with the Cryptand 4,7,13,16,21,24-Hexaoxa-1,10-diazabicyclo[8.8.8] hexacosane, J. Chem. Soc., Dalton Trans., 1979, 974-977.

40 F. Benetollo, G. Bombieri, A. Cassol, G. De Paoli and J. Legendziewicz, Coordination Chemistry of Lanthanides with Cryptands. An X-Ray and Spectroscopic Study of the Complex $\mathrm{Nd}_{2}\left(\mathrm{NO}_{3}\right)_{6}\left[\mathrm{C}_{18} \mathrm{H}_{36} \mathrm{O}_{6} \mathrm{~N}_{2}\right] \cdot \mathrm{H}_{2} \mathrm{O}$, Inorg. Chim. Acta, 1985, 110(1), 7-13.

41 G. Yang, S. Liu and Z. Jin, Coordination Chemistry and Structure Characterization of $\mathrm{C}_{18} \mathrm{H}_{36} \mathrm{O}_{6} \mathrm{~N}_{2} \mathrm{Eu}_{2}\left(\mathrm{NO}_{3}\right)_{6} \cdot \mathrm{H}_{2} \mathrm{O}$, Inorg. Chim. Acta, 1987, 131(1), 125-128.

42 U. Heinze, T. Heinze and D. Klemm, Synthesis and Structure Characterization of Lanthanum [2,2,2]Cryptates, $\left[\mathrm{LaCl}[2,2,2]\left(\mathrm{H}_{2} \mathrm{O}\right)\right] \mathrm{Cl} \cdot \mathrm{H}_{2} \mathrm{O}$ and $\left[\mathrm{La}\left(\mathrm{CF}_{3} \mathrm{SO}_{3}\right)[2,2,2](\mathrm{DMF})\right]$ $\left(\mathrm{CF}_{3} \mathrm{SO}_{3}\right)_{2}$, Macromol. Chem. Phys., 1999, 200(2), 896-902.

43 W. J. Evans, D. S. Lee, C. Lie and J. W. Ziller, Expanding the $\mathrm{LnZ}_{3} /$ Alkali-Metal Reduction System to Organometallic and Heteroleptic Precursors: Formation of Dinitrogen Derivatives of Lanthanum, Angew. Chem., Int. Ed., 2004, 43(41), 5517-5519.

44 W. J. Evans, D. S. Lee, D. B. Rego, J. M. Perotti, S. A. Kozimor, E. K. Moore and J. W. Ziller, Expanding Dinitrogen Reduction Chemistry to Trivalent Lanthanides via the $\mathrm{LnZ}_{3} /$ Alkali Metal Reduction System: Evaluation of the Generality of Forming $\operatorname{Ln}_{2}\left(\mu-\eta^{2}: \eta^{2}-N_{2}\right)$ Complexes via $\mathrm{LnZ}_{3} / \mathrm{K}, \mathrm{J}$. Am. Chem. Soc., 2004, 126(44), 14574-14582.

45 W. J. Evans, D. S. Lee and J. W. Ziller, Reduction of Dinitrogen to Planar Bimetallic $\mathrm{M}_{2}\left(\mu-\eta^{2}: \eta^{2}-\mathrm{N}_{2}\right)$ Complexes of Y, Ho, Tm, and Lu Using the $\mathrm{K} / \mathrm{Ln}\left[\mathrm{N}\left(\mathrm{SiMe}_{3}\right)_{2}\right]_{3}$ Reduction System, J. Am. Chem. Soc., 2004, 126, 454-455.

46 W. J. Evans, D. B. Rego and J. W. Ziller, Synthesis, Structure, and ${ }^{15} \mathrm{~N}$ NMR Studies of Paramagnetic Lanthanide Complexes Obtained by Reduction of Dinitrogen, Inorg. Chem., 2006, 45, 10790-10798.

47 D. Rinehart, M. Fang, W. J. Evans and R. Long, $\mathrm{A} \mathrm{N}_{2}{ }^{3-}$ Radical-Bridged Terbium Complex Exhibiting Magnetic Hysteresis at 14 K, J. Am. Chem. Soc., 2011, 133, 1423614239.

48 M. Fang, D. S. Lee, J. W. Ziller, R. J. Doedens, J. E. Bates, F. Furche and W. J. Evans, Synthesis of the $\left(\mathrm{N}_{2}\right)^{3-}$ Radical from $\mathrm{Y}^{2+}$ and Its Protonolysis Reactivity to Form $\left(\mathrm{N}_{2} \mathrm{H}_{2}\right)^{2-}$ via the $\mathrm{Y}\left[\mathrm{N}\left(\mathrm{SiMe}_{3}\right)_{2}\right]_{3} / \mathrm{KC}_{8}$ Reduction System, J. Am. Chem. Soc., 2011, 133(11), 3784-3787.

49 F. H. Allen, O. Kennard, D. G. Watson, L. Brammer, A. G. Orpen and R. Taylor, Tables of Bond Lengths Determined by X-Ray and Neutron Diffraction. Part 1. Bond Lengths in Organic Compounds, J. Chem. Soc., Perkin Trans. 2, 1987, (12), 1-19.

50 M. E. Fieser, D. H. Woen, J. F. Corbey, T. J. Mueller, J. W. Ziller and W. J. Evans, Raman Spectroscopy of the N-N Bond in Rare Earth Dinitrogen Complexes, Dalton Trans., 2016, 45(37), 14634-14644.

51 R. D. Shannon, Revised Effective Ionic Radii and Systematic Studies of Interatomie Distances in Halides and Chaleogenides, Acta Crystallogr., Sect. A: Cryst. Phys., Diffr., Theor. Gen. Crystallogr., 1976, 32, 751-767.

52 T. D. Tilley, R. A. Andersen, B. Spencer and A. Zalkin, Bis (pentamethylcyclopentadienyl)bis(pyridine)ytterbium(II), Inorg. Chem., 1982, 21(7), 2647-2649.

53 M. Schultz, J. M. Boncella, D. J. Berg, T. D. Tilley and R. A. Andersen, Coordination of 2,2'-Bipyridyl and 1,10Phenanthroline to Substituted Ytterbocenes: An Experimental Investigation of Spin Coupling in Lanthanide Complexes, Organometallics, 2002, 21(5), 460-472.

54 G. Nocton, C. H. Booth, L. Maron and R. A. Anderson, Influence of the Torsion Angle in 3,3'-Dimethyl-2,2'-bipyridine on the Intermediate Valence of $\mathrm{Yb}$ in $\left(\mathrm{C}_{5} \mathrm{Me}_{5}\right)_{2} \mathrm{Yb}\left(3,3^{\prime}-\right.$ $\mathrm{Me}_{2}$-bipy), Organometallics, 2013, 32(19), 5305-5312.

55 G. R. Willey, M. T. Lakin and N. W. Alcock, Unusual Crown Ether Encapsulation of a Chloroscandium(III) Cation. Structure of Threaded $\left[\mathrm{ScCl}_{2}\left(18\right.\right.$-crown-6)][ $\left.\mathrm{SbCl}_{6}\right]$, J. Chem. Soc., Chem. Commun., 1992, 21, 1619-1620.

56 M. D. Brown, W. Levason, D. C. Murray, M. C. Popham, G. Reid and M. Webster, Primary and Secondary Coordination of Crown Ethers to Scandium(III). Synthesis, Properties and Structures of the Reaction Products of $\mathrm{ScCl}_{3}(\mathrm{THF})_{3}, \mathrm{ScCl}_{3} \cdot 6 \mathrm{H}_{2} \mathrm{O}$ and $\mathrm{Sc}\left(\mathrm{NO}_{3}\right)_{3} \cdot 5 \mathrm{H}_{2} \mathrm{O}$ with Crown Ethers, Dalton Trans., 2003, 3(5), 857-865.

57 H. Yin, J. R. Robinson, P. J. Carroll, P. J. Walsh and E. J. Schelter, $\kappa^{2}$-Coordination of 18 -crown-6 to Ce(III) Cations: Solution Dynamics and Reactivity, Chem. Commun., 2014, 50(26), 3470-3472.

58 D. T. Tilley, R. A. Andersen, B. Spencer, H. Ruben and D. H. Templeton, Divalent Lanthanide Chemistry. Bis 
(pentamethylcyclopentadienyl)europium(II) and ytterbium(II) Derivatives: Crystal Structure of Bis(pentamethyIcyclopentadienyl)(tetrahydrofuran)ytterbium(II)-Hemitoluene at $176 \mathrm{~K}$, Inorg. Chem., 1980, 19, 2999-3003.

59 T. D. Tilley, J. M. Boncella, D. J. Berg, C. J. Burns, R. A. Andersen, G. A. Lawless, M. A. Edelman and M. F. Lappert, Bis[Bis(Trimethylsilyl)Amido]Bis(Diethyl Ether)Ytterbium and (Diethyl Ether)Bis $\left(\eta^{5}\right.$-Pentamethylcyclopentadienyl)Ytterbium, Inorg. Synth., 1990, 27, 146.

60 M. Schultz, C. J. Burns, D. J. Schwartz and R. A. Andersen, Solid-State Structures of Base-Free Ytterbocenes and Inclusion Compounds of Bis(pentamethyl- cyclopentadienyl)ytterbium with Neutral Carboranes and Toluene: The Role of Intermolecular Contacts, Organometallics, 2000, 19(9), 781-789.

61 D. C. Bradley, J. S. Ghotra and F. A. Hart, Three-co-ordination in Lanthanide Chemistry: Tris[bis(trimethylsilyl) amido]lanthanide(III) Compounds, J. Chem. Soc., Chem. Commun., 1972, 349-350.

62 W. J. Evans, T. M. Champagne and J. W. Ziller, Synthesis and Reactivity of Mono (pentamethylcyclopentadienyl) Tetraphenylborate Lanthanide Complexes of Ytterbium and Samarium: Tris(ring) Precursors to $\left(\mathrm{C}_{5} \mathrm{Me}_{5}\right) \mathrm{Ln}$ Moieties, Organometallics, 2007, 26(24), 12041211. 